\title{
Construction Project Leadership from the Perspective of Islam
}

\author{
MUHAMAD ROSDI SENAM*, KHAIRUDDIN ABDUL RASHID, \\ AZILA AHMAD SARKAWI \& RAPIAH MOHD. ZAINI ${ }^{1}$
}

\begin{abstract}
Construction industry is continuously being accused with common issues such as low performance, corruptions, spillages, bad practices in addition to common project failures despite advances in project management tools and techniques. This further adds to the existing and increasing complex and multi-facets business environment in construction projects that has resulted in the increasing pressure and challenges faced by project leaders and project managers today. Researchers in project management literature calls for more project leadership research as leadership now is increasingly recognised as project success factor. Ethical dilemma and leadership crisis facing the project managers and business organisations reveals the shortcomings and inadequacies of the conventional nonIslamic leadership that is believed to be or that has not fully considered the religious, spiritual, moral and ethical dimensions. Examples of these theories of leadership are authentic leadership, servant leadership and ethical leadership. Therefore, recent trend from literature has implicitly suggested a new form of leadership for construction project manager which is spiritual, moral, values and ethical form of leadership. The uniqueness of Islam is that it does not separate religion and other aspects of human life activities. Construction and project activities are part of the whole economic and social transactions of a nation and thus it is part of Islam. Project management in particular leadership awaits divine intervention that is tied to God consciousness and accords with values and principles prescribed in the Quran and Sunnah. This research is intended to overcome the spiritual and religious shortcomings of the present leadership models by proposing an Islamic perspective of leadership for construction project manager.
\end{abstract}

Keywords: construction management, Islamic leadership, leadership

It is commonly agreed in literature that leadership is the most critical factor in the success or failure of an organisation or institution (Bass 1990). It is subject that has long excited interest among people (Tirmizi 2002) and will continue to spark discussion, research and debates. Also, literature indicates, both leaders and managers, especially at the top management level, are keys to the success or failure of an organisation or business (Dahlena 2013). Effective leadership influences a group or organisation to achieve successfully and meet its goal and objectives (Osman \& Shuhaimi 2012). The leadership acts as an extra ingredient to the sum of

\footnotetext{
1 Muhamad Rosdi Senam*(Corresponding author), Ph.D. Student, Kulliyyah of Architecture and Environmental Design, International Islamic University Malaysia, 53100 KUALA LUMPUR, Malaysia, email: mrosdiS@jkr.gov.my; Khairuddin Abdul Rashid, Ph.D., Prof. Sr. \& Dean, Kulliyyah of Architecture and Environmental Design, International Islamic University Malaysia, 53100 KUALA LUMPUR, Malaysia, email: khairuddin@iium.edu.my; Azila Ahmad Sarkawi, Ph.D., Associate Professor, Kulliyyah of Architecture and Environmental Design, International Islamic University Malaysia, 53100 KUALA LUMPUR, Malaysia, email: azila@iium.edu.my; Rapiah Mohd. Zaini, Lecturer, Faculty of Management, Multimedia University 63100 CYBERJAYA, Selangor, Malaysia, email: rapiah@mmu.edu.my.
} 
efforts of many people and help the organisation to achieve or accomplish more than the normal achievement (Hitt et al. 2005; Osman \& Shuhaimi 2012). Thus, leadership is the energiser needed for people working a group or organisation, to get them motivated and moving effectively to achieve goals and eventually to achieve success, which management skills alone will be able to provide.

The study of project leadership is not new also in project management. Leadership is of fundamental importance to effective management of construction projects, independent of size, sector or location (Dainty et al. 2005; Bogus \& Rounds 2006) and therefore, leadership is important at all levels of construction administration from field supervision to company management (Bogus \& Rounds 2006). The importance of leadership for the overall project execution and eventually leading to project success is increasingly recognised in the project management literature. For example, Skipper and Bell (2006) state that the need for improved leadership skills in the construction industry is gaining recognition as an important issue and has attracted much recent attention. Limsila and Ogunlana (2008) state that effective leadership is essential for construction projects. Leadership is widely accepted as one of critical factors in determining the success or failure of a project (Amason et al. 2007).

Project managers are key players in projects and construction industry, and much of the fate of projects lies in their hands and rest on their shoulders. Their interpersonal skills and leadership in addition to the project management technical competencies will ensure smooth running of projects towards achieving its designated goals and success. The role of project manager is primarily to provide leadership to the entire project team from inception to completion to achieve project objectives and eventually project success (Zarina et al. 2012). In similar view, Gharehbaghi \& McManus (2003) point out that a major task of the project manager is to provide effective leadership throughout the life of a construction project leadership. The project manager's ability to successfully lead a team and achieve goals is and will always be critical to the success of a project (Hyvari 2006). Literature and research in project management that suggest the practice of transformational leadership for project manager in construction projects is found to be enormous. Example of previous research on transformational leadership for project manager in project environment have been conducted by the following authors in their published research; Barber and Warn (2005), Keegan and Den Hartog (2004), Davis (2008), Prabhakar (2005) and Murugesan (2012). Dyett (2011) in her doctoral research has stated that many state of the art studies on project leadership have been on transformational model of leadership. Keegan \& Den Hartog (2004) state that most of the current works and studies on leadership in both general management and project management literature have shown a great emphasis on the importance of transformational leadership. Barber \& Warn (2005) and Murugesan (2012) suggest that to be effective, project manager need to exhibit both transactional and transformational leadership style. Davis (2008) state that the study of transformational leadership is pertinent in project management and strong empirical data were presented in the literature review that transformational leadership is an effective leadership style in various settings. Davis (2008) concluded that his empirical research provide evidence that transformational leadership is the most effective in project management. His doctoral research has provided empirical data that transformational leadership behaviour leads to greater outcomes of efforts, effectiveness and satisfaction in project environment. Limsila \& Ogunlana (2008) conducted a study on project manager personal competencies and transformational leadership style in construction industry in Thailand. They found the positive relationship between project manager personal competencies and that practice of transformational leadership. In a survey on leadership for mega project, Toor \& Ogunlana (2006) observed that the attributes of transformational leaders were rated high as compared to those of transactional leaders. Thus, it can be stated that transformational leadership is paramount in project leadership and mostly quoted in project management literature. 
In the project management discipline, transformational leadership theory has empirical support, is socially significant in addressing the varying duties of the project manager, and is frequently referenced in research to explain the relationship between the project manager and project success (Dyett 2011). Barber and Warn (2005) introduced their 'Firelighter' theory for linking transactional (reactive) and transformational (proactive) leadership qualities with project management attributes. This theory is socially significant and useful to describe the range of behaviours of reactive and proactive project managers, and how these behaviours affect project success. However, research studies show that there is no agreement on what leadership style best suits the construction professionals and project managers. Toor (2008) argues that project managers tend to vary their leadership style at different stage of a project. Construction project follow a rapid life cycle rather than a static organisation that necessitating changes in organisational roles. Static organisation is a linear or functional line organisation as typical in manufacturing industry. The composition and dynamism of every team in project organisation is not the same which requires change in the style of leadership. Based on this consideration, situational leadership style is the other leadership style after transformational leadership for project managers. In relation to this, Copeland (2004) has suggested that the best model for leadership in a project environment is situational leadership.

On the other hand, however, dominant leadership models such as the transactional and transformational approaches to leadership, need to be rethought in spite of the relative 'effectiveness' of these approaches (Groves \& LaRocca 2011; Beekun 2012). For example, transformational leadership does not ensure behavioural ethicality or an emphasis on moral values (Groves \& LaRocca 2011; Dubrin 2012; Beekun 2012). Therefore, it is argued that the current leadership theories that are Western origin are absent in terms of spiritual, godconsciousness, ethics and moral values that are directly linked to religiosity. This is so because leadership is separated from religion in the Western models and organisation. This is totally opposite in the Islamic perspective as because Islam is a way of life than merely a religion (e.g. in Bilal et al. 2010). Toor (2007) says that recent works of leadership have also incorporated the concepts of spirituality and authenticity in leadership and leadership development. Examples of these theories of leadership are authentic leadership, servant leadership and ethical leadership. Toor (2008) argues that Islam provides the most comprehensive understanding of leadership through its highly developed and modern ethical system that seek guidelines from the Quran and the Sunnah of the Prophet s.a.w. Therefore, the aim of this paper is to highlight that the inadequacy and insufficiency in the present leadership practice in the construction projects that can be resolved by imbuting Islamic principles and values in the Islamic perspective of leadership.

\section{Construction Projects and Islamic Leadership}

As stated earlier, this paper aims to highlight the inadequacy and insufficiency in the present leadership practice in the construction projects particularly with regards to spirituality, ethics and religiosity. It is suggested that the inadequacy can be resolved by imbuting Islamic perspective of leadership. This is because a leadership model that is centered on ethics is in Islam since its beginning (Beekun \& Badawi 1999). Also, this is very much so, that according to Islam, the best way to find solutions to human problems is to use divine guidance (Syed Fayyaz 2007). The aim of this paper is supported by two research objectives as follows; to highlight the importance and benefits of Islamic perspective of project leadership, and to make a comparative analysis between conventional and Islamic perspective of project leadership. This paper is based on critical review of literature of project management and Islamic leadership, and also is based on the two main sources of revealed knowledge; Qur'anic verses and Prophetic statements (Hadith). 
The construction professionals particularly the project managers, being the most important person in the construction projects must be given the correct guidelines not only to deliver the physical projects successfully, but also to carry out the works, procedures, in the most correct ethical, moral and religious manner. Ahmad Shaheed (2012) suggests that project management from Islamic perspective is when we combine the classical or conventional project management tools and philosophies with examples from the Quran, the Sunnah Prophet s.a.w. and relevant case studies and this can make us more efficient in our service to humanity. From the perspective of Islamic leadership, it is to be based on Islamic sources of divine guidance prescribed in the Quran and the Sunnah of the Prophet s.a.w. For instance, Muslims actions are required to tie in with their intentions of committing such actions (niyyah). Intentions must be right to arrive at the true goals. In Islam, man' action is according to and beginning with his intention as famously said by the Prophet s.a.w. Any person involved in planning, construction and maintenance must ensure all activities are complying with the principles of Shari ah to get the pleasure of Allah or mardhatillah (e.g. by Ainul 2014). Examples of verses in the Quran mentioning about mardhatillah are in the following verses of Surah al-Baqarah: "And when it is said to him, 'Fear Allah', pride in the sin takes hold of him. Sufficient for him is Hellfire, and how wretched is the resting place" (2:206), "And of the people is he who sells himself, seeking means to the approval of Allah. And Allah is kind to (His) servants" (2:207), "And the example of those who spend their wealth seeking means to the approval of Allah and assuring [reward for] themselves is like a garden on high ground which is hit by a downpour - so it yields its fruits in double. And [even] if it is not hit by a downpour, then a drizzle [is sufficient]. And Allah, of what you do, is Seeing" (2:265).

Moreover, he or she, the project manager in the context of construction projects, must bear in mind and heart that any construction and project activity undertaken is to deliver his role as and for Allah's vicegerent (khalifah) on earth and not only for material satisfaction or merely to fulfil organisational needs, no matter how small the activity is. Acting as Allah's vicegerent (khalifah) also means that construction and project management activities are to be carried out in the most nice and ethical manner and cause no destructions and minimum waste to all mankind, the environment and other creations as Islam is against any form of corruption, transgression and destructions and in this regard, Allah says in the Quran in the Surah al-A'raf: "And cause not corruption upon the earth after its reformation. And invoke Him in fear and aspiration. Indeed, the mercy of Allah is near to the doers of good" (7:56). In another verse of the Quran, it is clear that Islam is always promoting good conduct and thus any acts of immorality and malpractices are forbidden as Allah clearly says in surah al-Nahl: "Indeed, Allah orders justice and good conduct and giving to relatives and forbids immorality and bad conduct and oppression. He admonishes you that perhaps you will be reminded" (16:90). In the context of construction projects, if this divine guidance can be followed and adhered to, then our project management practices will be free from ethical and moral issues, and this should result in greater efficiency and performance. Relying on and guiding by Shari'ah principles and Islamic leadership, project management professionals and their team members is to observe the ethical values to ensure their conducts of every project activities are in ethical and spiritual manner within the guidance and permissible limits of Islam. Islamic-based or God-conscious project manager or construction professionals will put Islamic leadership as a guide, thus leading and guiding the teams and projects in manners that are in accordance with the Islamic ways and values, in addition to the well-established project management and technical standard guidelines and construction practice. This will in the end make the project environment led by personnel that are balanced internally and externally, spiritually, emotionally and technically.

As many said construction projects for a long time have typical problematic challenges such as common fraudulence and unethical practices among project participants (Hamimah et al. 2011), also large waste, poor productivity, cost and time overruns as well as claims and disputes for a long time (Tey et al., 2011) and corruption, mismanagement and spillages (Ainul 
2014). Provided Islamic leadership principles and values are consistently in place and practiced, by managing projects in Islamic manners, since God-conscious (taqwa) project manager is highly moral and ethical individual, this can for example, overcome the problems associated with unethical behaviours and mismanagement in projects. Elements of God-consciousness and religion are clearly absent in the modern theories as in religion is a private matter and thus it is separated from leadership and daily activities in the Western models and organisation (e.g. Toor 2008). Many have viewed this as the root cause of ethical crisis and mismanagement issues in today's organisations. This is most likely because taqwa is the all-encompassing, inner consciousness of duty towards Allah (God-consciousness) and awareness of one's accountability towards Him (Khaliq 2007; Beekun \& Badawi 1999). Taqwa will restrain a leader from behaving wrongly and unjustly to followers and others. A individual project manager with taqwa will have a strong moral character that builds internally, from the inner parts of the body, thus have a clear Quranic and prophetic guidance on every of his actions in his project management related activities as well as in his private life. It will also result in a balanced project manager that is having a healthy state of emotional, mental and physical. This is actually the needs of today's project manager and construction professionals. From the project performance perspective, since Islam promotes and encourages that every task is to be performed at the individual's best level, as in the concept of itqan (work hard and perfection), it is anticipated that project performance will be enhanced and chances of project success is likely to be higher. Itqan means to strive for perfection, a criterion for achievement and excellence (Haque 2014). This is a great attitude that has been modelled by the Prophet Muhammad s.a.w. that can be exemplified by Muslims at work and all life activities. All his actions were done at the highest level of itqan. The concept of perfection or itqan is also associated with Allah s.w.t, as he says in the following verse of surah al-Naml (27:88): "And you see the mountains, thinking them rigid, while they will pass as the passing of clouds. [It is] the work of Allah, who perfected all things. Indeed, He is Acquainted with that which you do".

Apart from that, the leadership values in Islam can be expressed in one word, tawhid (Moten 2011). Thus, project managers from the perspective of Islamic leadership are guided by the Shari'ah, seek to practice good and avoid evil, in the course of actions seeking the pleasure of Allah and since the goal is mardhatillah, striving for the achievement of that goal assumes the form of worship or 'ibadah. An act of 'ibadah will receive reward from Allah s.w.t. This approach of managing projects will give totally different perspective in the way project managers, project team, and all other project stakeholders view project and project management from merely a series of definite tasks with defined processes and mechanistic procedures to achieve designated goals, to actions of tawhidic and taqwa, to get mardhatillah, amanah, ibadah and to be rewarded from Allah hereafter in addition to fulfil the needs of the conventional project approach.

It is also suggested in this paper that project manager is the Amir or the person in lead, from the Islamic perspective in construction project. The use of Amir for project manager as the leader in the construction context, has also been suggested by Ahmad Shaheed (2012). Amir also means the person who commands or has the power to command (Wan Kamal et al. 2012). In the Quran, it is also mentioned about Amir or al-Amri as the persons or individuals with authority. For example in the following surah al-Nisa' (4:83): "And when there comes to them information about [public] security or fear, they spread it around. But if they had referred it back to the Messenger or to those of authority among them, then the ones who [can] draw correct conclusions from it would have known about it. And if not for the favor of Allah upon you and His mercy, you would have followed Satan, except for a few". Table 1 below, from this study's review of literature and supported by the relevant ayat and hadith of the Prophet s.a.w. shows the comparison between the conventional project leadership and Islamic perspective of project leadership: 


\begin{tabular}{|c|c|c|}
\hline Criteria & Conventional & Islamic Perspective \\
\hline $\begin{array}{l}\text { 1.Objectives/ } \\
\text { goals }\end{array}$ & $\begin{array}{l}\text { To achieve project } \\
\text { success and satisfy } \\
\text { project stakeholders } \\
\text { (human needs) }\end{array}$ & 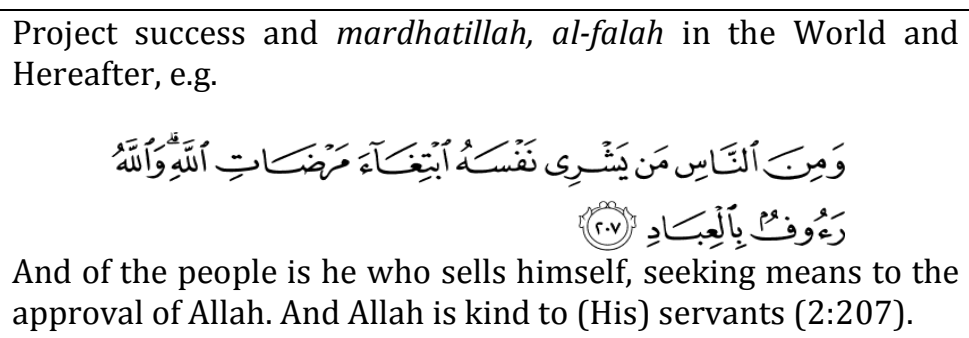 \\
\hline 2. Nature & $\begin{array}{l}\text { Merely humanistic } \\
\text { and technical } \\
\text { knowledge/process }\end{array}$ & $\begin{array}{l}\text { Humanistic, technical knowledge/process and God- } \\
\text { consciousness, e.g. } \\
0 \text { mankind, indeed We have created you from male and female } \\
\text { and made you peoples and tribes that you may know one } \\
\text { another. Indeed, the most noble of you in the sight of Allah is } \\
\text { the most righteous of you. Indeed, Allah is Knowing and } \\
\text { Acquainted (49:13). }\end{array}$ \\
\hline 3. Approach & $\begin{array}{l}\text { Materialistic } \\
\text { satisfaction }\end{array}$ & 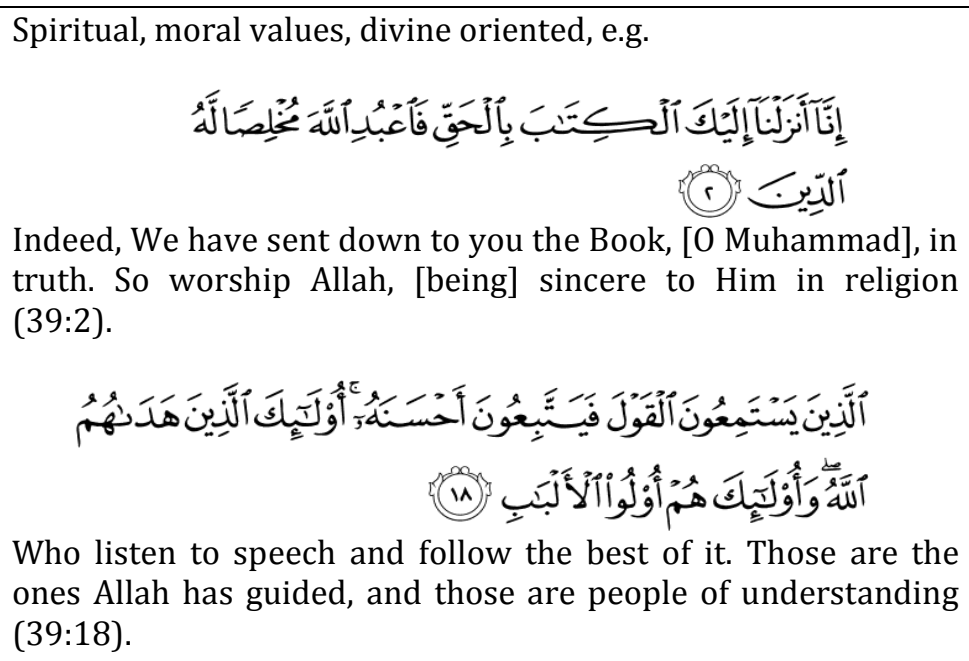 \\
\hline 4. Guidance & $\begin{array}{l}\text { Project Management } \\
\text { standard guidelines } \\
\text { e.g. PMBOK etc. }\end{array}$ & 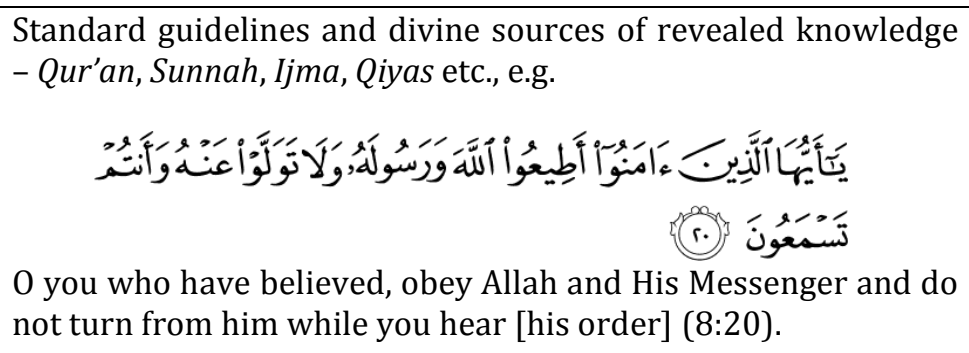 \\
\hline 5. Dimension & $\begin{array}{l}\text { Multidimensions } \\
\text { depends on how } \\
\text { organisations and } \\
\text { people define it }\end{array}$ & 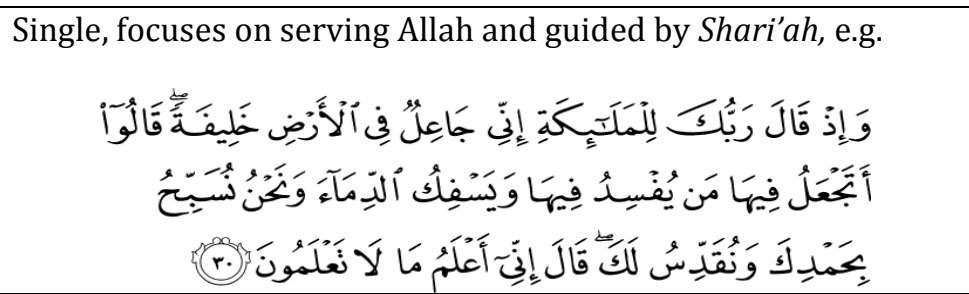 \\
\hline
\end{tabular}




\begin{tabular}{|c|c|c|}
\hline & & 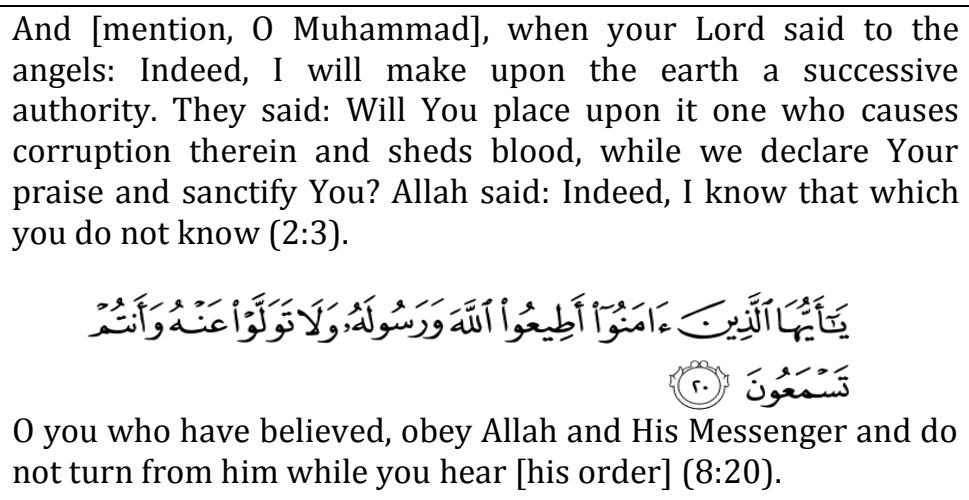 \\
\hline 6. Role model & $\begin{array}{l}\text { Not specific as } \\
\text { defined by each } \\
\text { project organization }\end{array}$ & $\begin{array}{l}\text { The Prophet s.a.w and the Wise Caliphs, e.g. } \\
\text { And indeed, you [Muhammad] are of a great moral character } \\
(68: 4) .\end{array}$ \\
\hline $\begin{array}{l}\text { 7. Leadership } \\
\text { role }\end{array}$ & $\begin{array}{l}\text { Leading and } \\
\text { motivating the project } \\
\text { team towards } \\
\text { objectives }\end{array}$ & 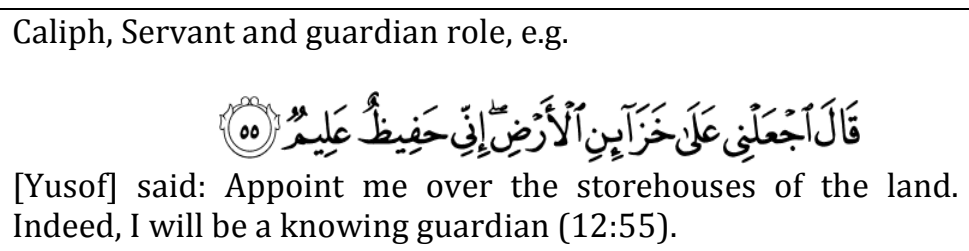 \\
\hline $\begin{array}{l}\text { 8. Sources of } \\
\text { motivation }\end{array}$ & $\begin{array}{l}\text { Materialistic rewards, } \\
\text { profits and } \\
\text { satisfaction }\end{array}$ & $\begin{array}{l}\text { Act as Ibadah and get rewards from Allah, e.g. } \\
\text { Whoever does a good deed - it is for himself; and whoever does } \\
\text { evil - it is against the self. Then to your Lord you will be } \\
\text { returned (45:15) }\end{array}$ \\
\hline $\begin{array}{l}\text { 9. Leadership } \\
\text { style }\end{array}$ & $\begin{array}{l}\text { Conventional theories } \\
\text { of leadership, } \\
\text { authoritative, let } \\
\text { alone, participative, } \\
\text { democratic as } \\
\text { necessary }\end{array}$ & $\begin{array}{l}\text { Participative and consultative, from the leadership of the } \\
\text { Prophet s.a.w wise Caliphs, Quranic scriptures and Hadith } \\
\text { quotes, e.g. } \\
\text { There has certainly been for you in the Messenger of Allah an } \\
\text { excellent pattern for anyone whose hope is in Allah and the Last } \\
\text { Day and [who] remembers Allah often (33:21). }\end{array}$ \\
\hline $\begin{array}{c}\text { 10. Problem } \\
\text { solving }\end{array}$ & $\begin{array}{l}\text { Conventional } \\
\text { approach }\end{array}$ & $\begin{array}{l}\text { Shura (consultation), Nasihah (advice), Taa'wun (cooperation), } \\
\text { e.g. }\end{array}$ \\
\hline
\end{tabular}




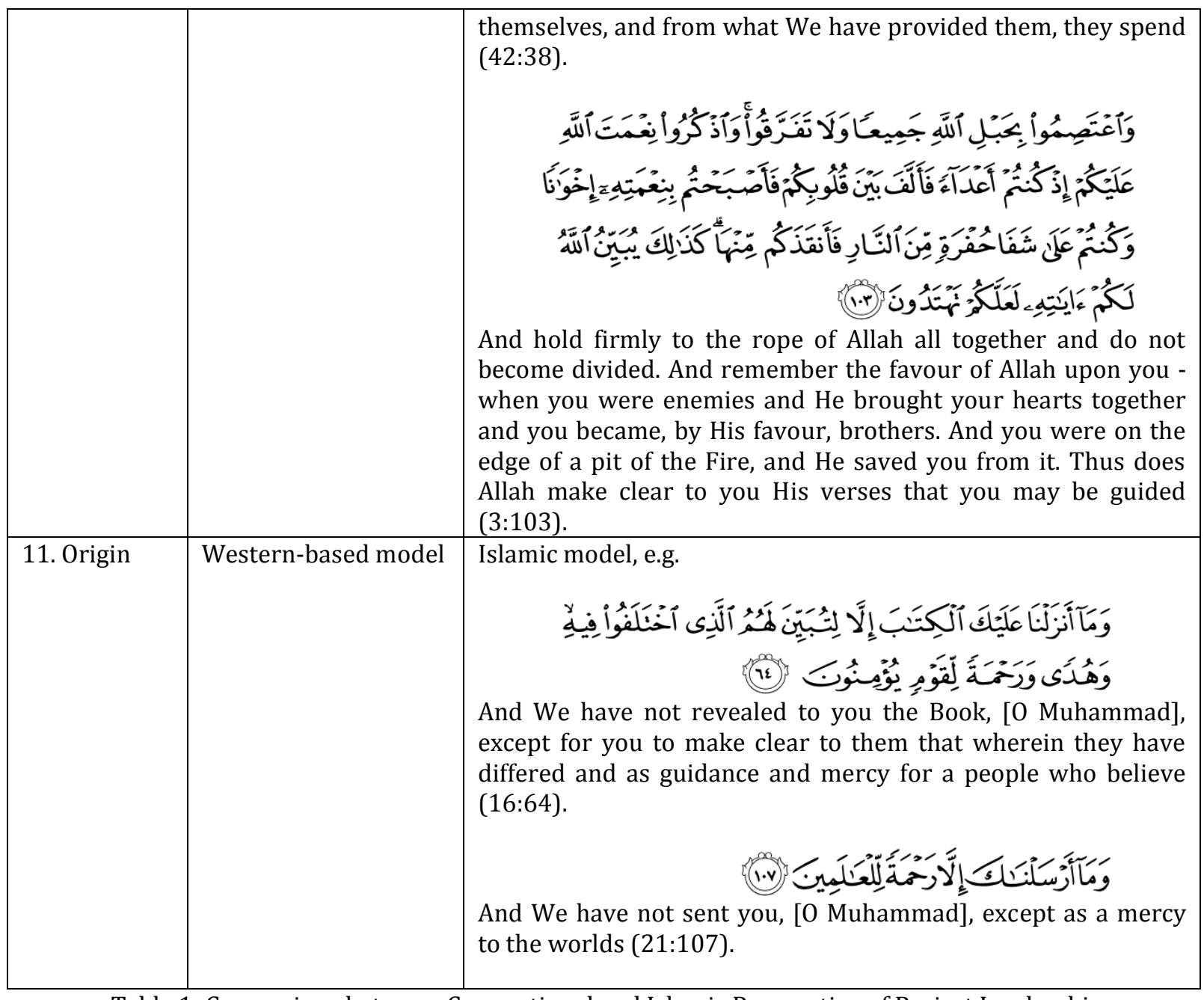

Table 1: Comparison between Conventional and Islamic Perspective of Project Leadership

\section{Discussions and Conclusion}

Among the major differences from the comparison between the conventional and Islamic perspective of project leadership is that materialistic achievement by way of meeting the project success criteria and fulfilling the satisfaction of client and stakeholders in the conventional model. This is the ultimate goals in the present conventional project leadership as contrasted with seeking the pleasure of Allah s.w.t is the goal in Islamic leadership. There is a clear absence of spiritual and religious components in the present system of project leadership and project management as a whole as discussed before and shown in Table 1. Islamic leadership is guided by the sources of revealed knowledge mainly the Qur'an and Sunnah of the Prophet s.a.w. as the sources of guidance, in contradiction to this, in the conventional models of leadership and management, there is no specific sources of guidance, varies and different according to interpreted values, ethics, code of conducts, cultures, races and organisational needs.

Most of the prevalent leadership theories in the mainstream of general management and project management studies and literature, and also the empirical evidence supporting them are distinctly American or European in character and they emphasise values that are individualistic, hedonistic and rational as against collectivist, altruistic and religion (Moten 2011). Thus, values that are derived from religion is ignored in those leadership theories. The major component of the Western leadership theories is they separate individual and professional life. Key attributes of leadership are experience, expertise and decision-making 
skills needed to accomplish tasks, achieve goals and ensure self-interest. Not much attention is given to values and ethics for the leader character which is considered by many at the root of contemporary leadership crisis (Moten 2011). As also mentioned in previous paragraph, on the other hand, leadership from Islamic perspective is a trust (amanah) and rooted in the Qur'an, literally the word of Allah and Sunnah, sayings and doings of Prophet Muhammad s.a.w. The leadership values in Islam can be expressed in one word, tawhid. Thus, leaders are guided by the Shari'ah, seek to practice good and avoid evil, in the course of actions seeking the pleasure of Allah and since the goal is divine, striving for the achievement of that goal assumes the form of worship or ibadah. All these characters and values clearly and distinctly differentiate the conventional and contemporary leadership with the Islamic perspective leadership.

Construction projects face huge challenges and are commonly being accused with low performance, corruptions, spillages, fraudulence and unethical practices among project participants, cost and time overruns in addition to common project failures despite advances in project management tools and techniques. Effective leadership is essential for construction projects. Leadership is widely accepted as one of critical factors in determining the success or failure of a project and project management is a leader-intensive activity and effective leadership by itself can go far towards ensuring that a project will be a success.

Project managers are key players in projects and construction industry, and much of the fate of projects lies in their hands and rest on their shoulders through interpersonal skills and their vital leadership role they play in addition to the project management technical competencies. This is to ensure smooth running of projects towards achieving its designated goals and success. The role of project manager is primarily to provide leadership to the entire project team from inception to completion to achieve project objectives and eventually project success. It is suggested in this paper that project performance can be enhanced and malpractices can be overcome by imbuting Islamic leadership principles. In practising Islamic leadership values and principles, project managers and their team members are to observe the ethical values to ensure their conducts of every project activities are in ethical and spiritual manner within the guidance and permissible limits of Islam. Islamic-based or God-conscious project manager or construction professionals will put Islamic leadership as a guide, thus leading and guiding the teams and projects in manners that are in accordance with the Islamic ways and values, in addition to the well established project management standard guidelines. This will overcome issues associated with ethics and morals. The concept of mardatillah and itqan (work hard and perfection), if is properly practice in place, it is anticipated that project performance will be enhanced and chances of project success is likely to be higher. Itqan means to strive for perfection, a criterion for achievement and excellence as modelled by the Prophet s.a.w.

\section{References}

Al-Quran.

Ahmad Shaheed. 2012. Project management from Islamic perspective. http://wdmleadershipforum.files.wordpress.com/2012/12/project-management-froman-islamic-perspective1.pdf. [6 January 2014].

Ainul Jaria Maidin. 2014. Developing rules from shari'ah for promoting efficient construction practices. The $2^{\text {nd }}$ IIUM-Kyoto University Postgraduate Colloquium - Shari'ah Compliance Issues in Construction. IIUM, $8^{\text {th }}$ May.

Amason, A., Aronson, Z., Dominick, P., Holahan, P., Lechler, T., Mooney, A., Reilly, R. \& Shenhar, A. 2007. The Human Side of Project Leadership. Newton Square: Project Management Institute.

Barber, E. \& Warn, J. 2005. Leadership in project management: From firefighter to firelighter. Management Decision 43(7): 1032-1039. 
Bass, B.M. 1990. Bass \& Stogdill's Handbook of Leadership. 3 ${ }^{\text {rd }}$ Ed. New York: The Free Press.

Beekun, R.I. \& Badawi, J. 1999. Leadership: an Islamic Perspective. Maryland: Amana Publications.

Beekun, R.I. 2012. Character centered leadership: Muhammad (p) as an ethical role model for CEOs. Journal of Management Development 31(10): 1003-1020.

Bilal, K., Ayesha Farooq \& Zareen Hussain. 2010. Human resource management: An Islamic perspective. Asia Pacific Journal of Business Administration 2(1): 17-34.

Bogus, S.M. \& Rounds, J.I. 2006. Incorporating leadership skill development in construction training program. $2^{\text {nd }}$ Specialty Conference on Leadership and Management in Construction.

Copeland, S. 2004. Leadership a pre-requisite for success. http://www.projectmagazine.com/leadership-skills/184-leadership-a-prerequisite-forsuccess. [11 January 2014].

Dahlena Sari Marbun. 2013. Attributions and requirements of Islamic leadership. Management Research Review 36(4): 379-387.

Dainty, A.R.J., Cheng, M. \& Moore, D. 2005. Competency-based model for predicting construction project managers' performance. ASCE Journal of Management in Engineering 21(1): 2-9.

Davis, A. 2008. Leadership style in project management: An analysis bases upon the multifactor leadership questionnaire. Ph.D. Thesis, Capella University.

Dubrin, A. 2012. Leadership: Research Findings, Practice and Skills. 7th Ed. Boston: Houghton Mifflin.

Dyett, V. 2011. Roles and characteristics of the project manager in achieving success across the project life cycle. Ph.D. Thesis, Lynn University.

Gharehbaghi, K. \& McManus, K. 2003. The construction manager as a leader. Leadership and Management in Engineering 3(1): 56-58.

Groves, K.S. \& La Rocca, M.S. 2011. Responsible leadership outcomes via stakeholder CSR values: Testing a value-centered model of transformational leadership. Journal of Business Ethics 98: 37-55.

Hamimah Adnan, Norfashiha Hashim, Norazian Mohd Yusuwan \& Norizan Ahmad. 2011. Ethical issues in the construction industry: Contractor's perspective. Asia Pacific International Conference on Environment-Behaviour Studies. North Cyprus, 7-9 December.

Haque, Sheikh Munawar. n.d. The concept of itqan. http://www.amda.us/khutba_transcripts/ Concept_of_Itqan_in_Islam_Sheikh_Munawar_Haque.pdf. [11 July 2014].

Hitt, M., Black, S. \& Porter, L.W. 2005. Management. New Jersey: Pearson Education Inc.

Hyvari, I. 2006. Success of projects in different organisational conditions. Project Management Journal 37(4): 31-41.

Keegan, A. \& Den Hartog, D. 2004. Transformational leadership in a project-based environment: A comparative study of the leadership styles of project managers and line managers. International Journal of Project Management 22: 609-617.

Khaliq, A. 2007. Leadership and work motivation from the Islamic perspective. Paper presented at International Conference on Management from Islamic Perspective. Organised by IIUM. Kuala Lumpur, 15-16 May.

Limsila, K. \& Ogunlana, S.O. 2008. Linking personnel competencies with transformational leadership style evidence from construction industry in Thailand. Journal of Construction in Developing Countries 13(1): 27-50.

Moten, A.R. 2011. Leadership in the West and the Islamic world: A comparative analysis. World Applied Sciences Journal 15(3): 339-349.

Murugesan, R. 2012. Characteristics and skills of leadership for project performance. Journal of Business Management \& Social Sciences Research 1(3): 1-9. 
Osman Abdullah @ Chuah Hock Leng \& Mohd. Shuhaimi Ishak. 2012. Conceptual framework of good management from the Islamic perspective. International Journal of Business and Management Studies 4(1): 185-195.

Prabhakar, G.P. 2005. Switch leadership in projects: An empirical study reflecting the importance of transformational leadership on projects success across twenty-eight nations. Project Management Journal 36(4): 53-60.

Skipper, C.O. \& Bell, L.C. 2006. Influences impacting leadership development. Journal of Management in Engineering April: 68-74.

Syed Fayyaz, A. 2007. Ethical basis of organisational perspective: An Islamic perspective. Paper presented at International Conference on Management from Islamic Perspective. Organised by IIUM. Kuala Lumpur, 15-16 May.

Tey Kim Hai, Syuhaida Ismail \& Aminah Md. Yusof. 2011. The challenges of construction project management through coordination for sustainable development. Paper presented at National Seminar on Assets and Project Management. Petaling Jaya, November, 22.

Tirmizi, S.A. 2002. The 6-L framework: A model for leadership research and development. Leadership and Organization Development Journal 23(5): 269-279.

Toor S.R. \& Ogunlana S.O. 2006. Successful project leadership: Understanding the personality traits of project managers and organizational factors. In Proceedings of the CIB W107, Construction in Developing Economies International Symposium. Santiago, Chile.

Toor, S.R. 2007. An Islamic leadership theory: Exploring the extra dimensions. Paper presented at International Conference on Management from Islamic Perspective. Organised by IIUM. Kuala Lumpur, 15-16 May.

Toor, S.R. 2008. Merging spirituality and religion: Developing an Islamic leadership theory. IIUM Journal of Economics and Accounting 16(1): 15-46.

Wan Kamal Mujani, Ezad Azraai Jamsari, Noor Inayah Ya'akub, Hamzaini Abdul Hamid, Wan Mohtar Wan Yusoff, Nur Riza Mohd. Suradi, Zinatul Ashiqin Zain et al. 2012. Meaning of leadership according to Islam. Advances in Natural and Applied Sciences 6(8): 13941398.

Zarina Alias, Zarita Ahmad \& Muhammad Fahmi Mad Idris. 2012. Project management towards best practice. ASIA Pacific International Conference on Environment-Behaviour Studies. Egypt, 31 October - 2 November. 